\title{
The levels of mercury, methylmercury and selenium and the selenium health benefit value in grey-eel catfish (Plotosus canius) and giant mudskipper (Periophthalmodon schlosseri) from the Strait of Malacca
}

\begin{abstract}
The present study examined the concentrations of mercury $(\mathrm{Hg})$, methylmercury $(\mathrm{MeHg})$, and selenium (Se) in the multiple tissues of the Plotosus canius and Periophthalmodon schlosseri collected from the Strait of Malacca. The mean value in $\mathrm{mg} \mathrm{kg}-1$ of $\mathrm{Hg}$ (P. canius: $0.34 \pm 0.19$; P. schlosseri: $0.32 \pm 0.18$ ) and $\mathrm{MeHg}$ in muscle (P. canius: $0.14 \pm 0.11$; P. schlosseri: $0.17 \pm 0.11)$ were below the Codex general standard for contaminants and toxins in food and feed (CODEX STAN 193-1995), the Malaysian Food Regulation 1985 and the Japan Food Sanitation Law. For P. canius, the liver contained the highest concentrations of $\mathrm{Hg}(0.48 \pm 0.07 \mathrm{mg} \mathrm{kg}-1)$ and $\mathrm{MeHg}(0.21 \pm 0.00 \mathrm{mg} \mathrm{kg}-1)$, whereas for P. schlosseri, the gill contained the highest concentrations of $\mathrm{Hg}(0.36 \pm 0.06 \mathrm{mg} \mathrm{kg}-1)$ and $\mathrm{MeHg}(0.21 \pm$ $0.05 \mathrm{mg} \mathrm{kg}-1)$. The highest concentration of $80 \mathrm{Se}(\mathrm{mg} \mathrm{kg}-1)$ was observed in the liver of $\mathrm{P}$. canius $(20.34 \pm 5.68)$ and in the gastrointestinal tract $(3.18 \pm 0.42)$ of P. schlosseri. The selenium:mercury (Se:Hg) molar ratios were above 1 and the positive selenium health benefit value (HBVSe) suggesting the possible protective effects of Se against $\mathrm{Hg}$ toxicity. The estimate weekly intakes (EWIs) in $\mu \mathrm{g} \mathrm{kg}-1$ body weight (bw) week-1 of $\mathrm{Hg}$ (P. canius: 0.27 ; P. schlosseri: 0.15) and MeHg (P. canius: 0.11; P. schlosseri: 0.08) were found to be lower than the provisional tolerable weekly intake established by the Joint FAO/WHO Expert Committee on Food Additives (JECFA). Based on the calculated EWIs, P. canius, and P. schlosseri were found to be unlikely to cause mercury toxicity in human consumption.
\end{abstract}

Keyword: Demersal fish; Food safety; Mercury; Methylmercury; Selenium 